\title{
Submarine glacial-landform distribution across the West Antarctic margin, from grounding line to slope: the Pine Island-Thwaites ice-stream system
}

\author{
A. G. C. GRAHAM ${ }^{1 *}$, M. JAKOBSSON${ }^{2}$, F. O. NITSCHE ${ }^{3}$, R. D. LARTER ${ }^{4}$, J. B. ANDERSON ${ }^{5}$, C.-D. HILLENBRAND ${ }^{4}$, \\ K. GOHL ${ }^{6}$, J. P. KLAGES ${ }^{6}$, J. A. SMITH $^{4}$ \& A. JENKINS ${ }^{4}$ \\ ${ }^{1}$ College of Life and Environmental Sciences, University of Exeter, Rennes Drive, Exeter EX4 4RJ, UK \\ ${ }^{2}$ Department of Geological Sciences, Stockholm University, Svante Arrhenius väg 8, 10691 Stockholm, Sweden \\ ${ }^{3}$ Lamont-Doherty Earth Observatory, Columbia University, Palisades, New York 10964, USA \\ ${ }^{4}$ British Antarctic Survey, Natural Environment Research Council, High Cross, Madingley Road, Cambridge CB3 OET, UK \\ ${ }^{5}$ Department of Earth Sciences, Rice University, 6100 Main Street, Houston, Texas 77005, USA \\ ${ }^{6}$ Alfred Wegener Institute, Helmholtz Centre for Polar and Marine Research, Am Alten Hafen 26, D-27568 Bremerhaven, Germany \\ *Corresponding author (e-mail: a.graham@exeter.ac.uk)
}

About $30 \%$ of ice draining the West Antarctic Ice Sheet discharges through several glacier systems into the Amundsen Sea Embayment (ASE) (Fig. 1a). Two major ice-stream outlets, Pine Island and Thwaites glaciers, have undergone significant twentieth century changes (e.g. Rignot et al. 2008) and much effort has focused upon understanding their late Quaternary glacial history (Larter et al. 2014). At the Last Glacial Maximum (LGM), the ice sheet in the ASE expanded to reach the outer shelf and is postulated to have reached the shelf edge (Graham et al. 2010). The Pine Island and Thwaites glaciers combined regularly through Quaternary glaciations to carve out a $>500 \mathrm{~km}$ long trough that extends from the shelf break back to the modern-day grounding line and beyond. Geophysical data exist for the breadth of this transect, including sub-ice-shelf bathymetry (Jenkins et al. 2010), making it one of the most complete palaeo-ice-stream landsystems known offshore of Antarctica. Deglaciation of the trough was underway by c. 20 cal. ka BP and was episodic, reaching a mid-shelf position by $c .13 .5-12$ cal. ka $\mathrm{BP}$ and retreating rapidly to the inner ASE by $c$. 11-9 cal. ka BP (Kirshner et al. 2012; Hillenbrand et al. 2013; Smith et al. 2014). Repeated pauses and several phases of ice-shelf break-up have been interpreted to have taken place during deglaciation based upon a well-preserved landform and sediment record (Lowe \& Anderson 2002; Graham et al. 2010; Jakobsson et al. 2011).

A single-channel seismic line collected in 1999 demonstrates that the trough is floored by crystalline or deformed sedimentary bedrock on the inner shelf, overlain by progressively younger, indurated to unlithified sedimentary strata farther offshore (Fig. 1c; Lowe \& Anderson 2002). On the mid-to-outer shelf these sediments form a significant stacked prograded to aggrading wedge. Material from the inner shelf has largely been removed by more recent phases of ice-sheet erosion, leaving dipping ancient sediments cropping out at or near the seafloor (Fig. 1c). Based on comparison with similar seismic packages in the Ross Sea, the geological units are interpreted to range in age from Cretaceous to Quaternary (Gohl et al. 2013). The outer-shelf seismic stratigraphy shows cycles of erosion and deposition by ice streams that maintained a broadly consistent flow path through time (Gohl et al. 2013). The overall geological context is, therefore, one of repeated glaciation and deglaciation since at least the Miocene.

The submarine landforms described here formed (or were modified) during the last cycle of ice-sheet growth and decay since $c .21$ ka ago. For simplicity, the landform set illustrated is limited to seafloor features that occupy the main trunk of the ice stream which flowed along Pine Island Trough and had a main outlet towards the east (the Pine Island Trough East or PITE; Graham et al. 2010). However, we note that readvances of the ice stream along a second outlet, Pine Island Trough West (PITW), have also been inferred from directional landform evidence (Jakobsson et al. 2011), and that more complex outer-shelf landform suites are present either side of the inferred outlet (e.g. in the PITW, Evans et al. 2006; and in Abbot Trough, Klages et al. 2015).

\section{Description of landforms}

\section{Grounding line/sub-ice shelf}

Missions of the UK Natural Environment Research Council Autosub-3 Autonomous Underwater Vehicle (AUV) in 2009 acquired seafloor bathymetry beneath Pine Island Glacier ice shelf (Jenkins et al. 2010; Fig. 2a). Closest to the grounding line, the geomorphology of the sub-ice-shelf environment consists of broadly parallel, conformable and streamlined ridge-groove landforms, with wavelengths of $c .130-400 \mathrm{~m}$ and amplitudes of c. $2-7 \mathrm{~m}$ (Fig. 2b). Individual ridge lengths are $\geq 1 \mathrm{~km}$ (inferred from the oblique nature of the line) and elongate in the direction of modern ice-shelf and assumed former glacier flow. The linear forms cover the back-slope of a large $c .400 \mathrm{~m}$ high bedrock-cored sub-ice-shelf ridge that lies mid-way between the 2009 location of the grounding line and the ice-shelf front. The top of this ridge is notably flat over a distance of $c .3 \mathrm{~km}$, interpreted as a remnant of erosional 'planing' by past glacier flow (Graham et al. 2013). In the along-flow direction, streamlined landforms extend across the top of the ridge (Fig. 2c). In the groove between two of the well-imaged elongate linear ridges, a set of 24 regularly spaced low-amplitude transverse corrugated ridges ('corrugations') is observed (Fig. 2c). These have wavelengths averaging $84 \mathrm{~m}$ crest-to-crest and amplitudes ranging from 0.2 to $0.7 \mathrm{~m}$. They decrease slightly in spacing downstream, and exhibit a possible cyclicity in both spacing and height on the order of 11-13 ridges. The corrugations terminate at the ridge crest, beyond which the ice-distal face of the sub-ice-shelf ridge exhibits locally lobate and channelized features, but is featureless elsewhere.

At the toe of the ridge close to the ice-shelf front, a single cragand-tail drumlinoid landform is mapped on the seafloor (Fig. 2d). The flanks of the drumlin head are eroded by a number of gullies and in places small chutes provide evidence for local, fine-scale sediment slope instability. A sinuous, $14 \mathrm{~m}$ deep and $160 \mathrm{~m}$ wide U-shaped channel appears to incise the landform tail, possibly for several kilometres (Fig. 2d).

\section{Inner shelf}

Pine Island Trough extends from beneath the current ice-shelf front arcing northwards to the shelf break (Fig. 1a). The inner-shelf part of the trough is convergent with morphologically similar deeply carved tributaries emanating from the Thwaites and Smith glaciers to the west (Fig. 1b). At its deepest, the trough is $c .1600 \mathrm{~m}$ deep and $>60 \mathrm{~km}$ wide.

The crag-and-tail feature observed under the ice shelf is typical of landforms mapped on the rugged inner shelf immediately seaward of the modern ice front. The palaeo-ice-stream bed here comprises streamlined crag-and-tails, highly elongate drumlinoid spindles and ridge-groove landforms (Fig. 2e). Bedforms are

From: Dowdeswell, J. A., Canals, M., Jakobsson, M., TodD, B. J., Dowdeswell, E. K. \& Hogan, K. A. (eds) 2016. Atlas of Submarine Glacial Landforms: Modern, Quaternary and Ancient. Geological Society, London, Memoirs, 46, 493-500, http://doi.org/10.1144/M46.173 (C) 2016 The Author(s). Published by The Geological Society of London. All rights reserved. For permissions: http://www.geolsoc.org.uk/permissions. Publishing disclaimer: www.geolsoc.org.uk/pub_ethics 


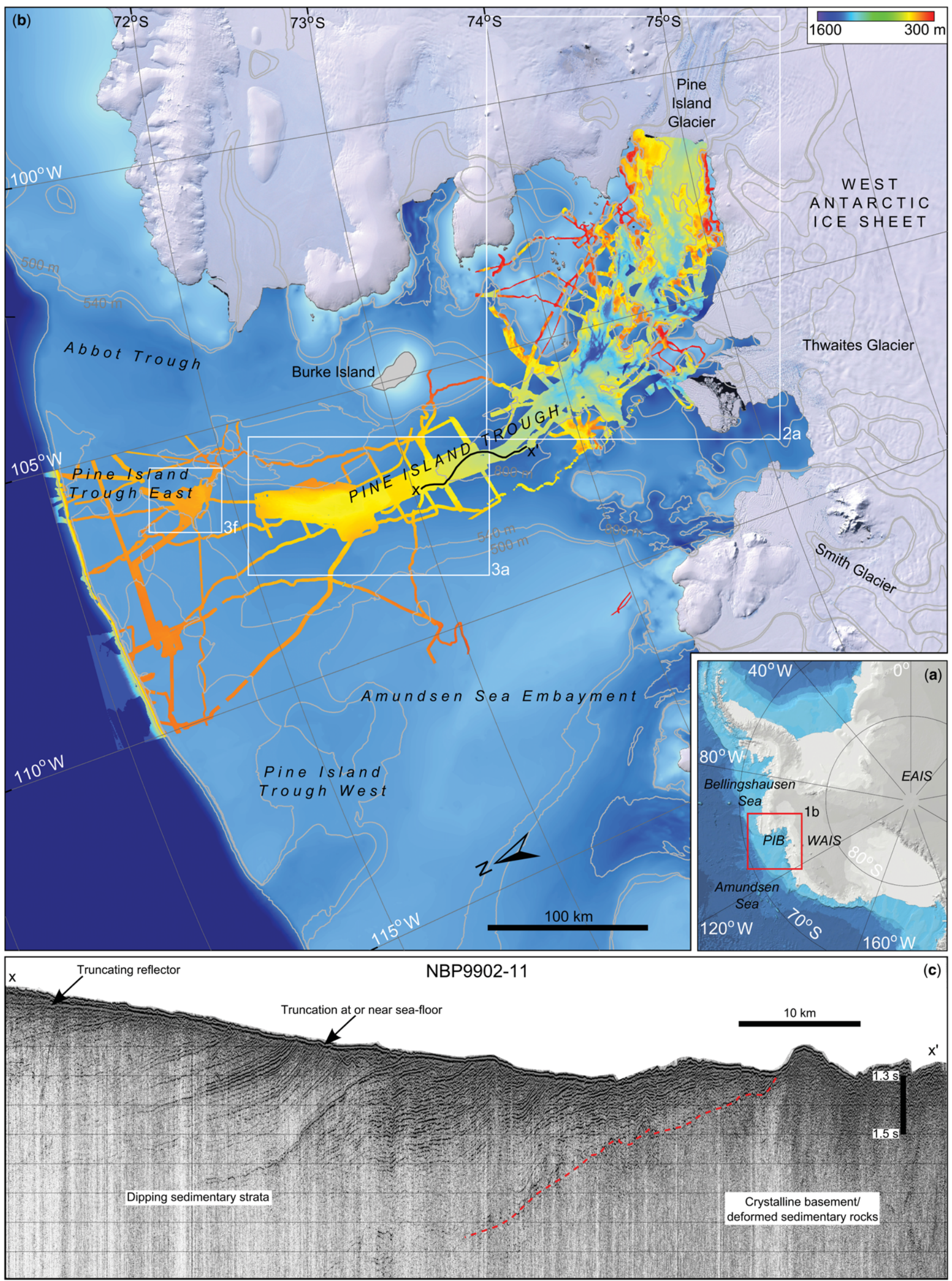

Fig. 1. Bathymetry and seismic architecture of the Pine Island Trough region, West Antarctica. (a) Location of study area (red box; map from IBCSO v. 1.0). (b) Multibeam-bathymetric data for the eastern Amundsen Sea Embayment, collated from various published datasets (UK, German, Swedish and US). (c) Seismic line NBP9902-11 from the middle shelf of Pine Island Trough (77 km long; shots 1-4000; located in (b)). The clear boundary between crystalline bedrock and seaward-dipping sedimentary strata is marked in red. Tilted strata are truncated at or near the seafloor along the length of the line. Depth scale in two-way travel time. 
pronounced in regions of thin sediment cover, interspersed by zones of relatively flat seafloor that are known from seismic (Nitsche et al. 2013) and sub-bottom profiler data to be sedimentfilled depressions, and by prominent bedrock protuberances or highs that commonly form the seed points (crags) for downstream sediment tails.

On a basin-wide scale, the inner shelf is characterized by a consistent pattern of relatively small isolated depressions (basins) and intervening trough-crossing sills/highs that are dissected by sub-troughs or channels that link many of the basins together (Fig. 2f ). Sills often follow linear tracks that reflect the dominant geological structure of the shelf in this locality (Fig. 2g).

Several of the sills are particularly shallow (up to $c .450 \mathrm{~m}$ depth) and stretch across Pine Island Trough for nearly its entire width, cut through by channels in a few places (Fig. $2 \mathrm{f}, \mathrm{g}$ ). This broad-scale rough topography is superimposed by complex ice-sculpted bedforms on a local scale. Deep portions of the landscape, especially basin floors, show subglacial landforms such as small parallel drumlins, grooves and short linear ridges as well as sinuous channels and rarer but larger, meandering tunnel valleys (Fig. 2f).

Towards the middle shelf, the channels and basins interconnect and well-developed ice-flow bedforms are present in a single, relatively well-defined trough. Near the transition between crystalline bedrock outcrop and dipping sedimentary strata (Fig. 1c), the rough and high-relief inner shelf gives way to a smoother regional topography on which fine-scale glacial landforms are more prominent (Fig. 2h). The trough floor in this region is heavily streamlined, shaped into parallel linear ridge-groove sets. Numerous channels orientated perpendicular to palaeo-flow as indicated by the streamlined landforms break up the streamlined topography. These channels have been variously interpreted as structural elements of the landscape and meltwater-eroded forms (Lowe \& Anderson 2003), but are likely to represent locations in which ice (and water) preferentially exploited weaker sedimentary outcrops at the seafloor. Some of the fine-scale non-aligned grooves are almost certainly faults or joints in the bedrock structure.

\section{Mid-shelf trough (grounding-zone wedges)}

North of $73^{\circ} \mathrm{S}$, the Pine Island/Thwaites tributary troughs converge into a single trough on the mid-shelf, $c .60 \mathrm{~km}$ wide and $\mathrm{U}$-shaped in profile. The seafloor remains locally rugged with isolated sills separating areas (Fig. 2). Heavily streamlined landforms dominate the topography. Locally, bedforms comprise a mixture of large crag-and-tails, drumlinoid ridges and streamlined grooves which vary in elongation from long and narrow to short and stubby. Pronounced crescentic scours and sinuous channels flank the upstream ends of several crags (Fig. 2i).

Seaward of the last prominent bedrock sill, landforms consist of drumlins with long tails evolving downflow into highly parallel, mega-scale linear ridges (Fig. 3). This evolution coincides with the geological boundary between bedrock outcrop and sedimentary strata as mapped from seismic-reflection profiles across the shelf (Figs 1b, 4a). At $73^{\circ} 36^{\prime} \mathrm{S}$, a $50 \mathrm{~m}$ high seafloor ramp is imaged across the trough that is broadly asymmetrical in profile and is $\mathrm{V}$-shaped in planform, with a crest pointing downflow. Elongate lineations on the crest and flank of the ramp terminate at the crest, but seismic data suggest that the ridge is bedrock rather than a morphologically similar grounding-zone deposit (Fig. 1c).

Two further wedge-shaped asymmetrical landforms fill the centre of the trough across its width to the north (Fig. 3a, b). These comprise two of a series of five sediment wedges described previously across the palaeo-ice-stream bed (GZW1-5; Graham et al. 2010; Jakobsson et al. 2012). GZW5 partially overlies GZW4, extending for $22 \mathrm{~km}$ along the axis, and has a maximum thickness of up to $c .55 \mathrm{~m}$. GZW4 is smaller, $c .20 \mathrm{~m}$ thick and extends for $c .18 \mathrm{~km}$ (although it probably underlies GZW5 for a considerable distance). Streamlined lineations are well developed on the surface of GZW4, whereas the top and back-slope of GZW5 are characterized by cross-cutting, sinuous and randomly aligned V-shaped ploughmarks to a depth of $c .750 \mathrm{~m}$ (Fig. 3b). Further down the back-slope of GZW5, where the water deepens, furrows give way to an extensive set of elongate and parallel mega-scale lineations that cover the trough floor uniformly, and are orientated along the trough axis.

The set of lineations on top of GZW4 extend over and beyond the ridge crest to the north and west, where the seafloor remains shallow, at the height of the wedge surface. The lineations partially extend into the PITW which branches off from the main trough at this location (Fig. 1b). In contrast, in the deeper main axis of the trough, the seafloor comprises a series of back-stepping smaller transverse ridges that combine to form a subdued sedimentary body that deepens inland (GZW3). This wedge and ridge complex extends only partially across the trough floor, but continues for $c .16 \mathrm{~km}$ along the trough. To the north, beyond both the lineations and GZW3, a separate set of large curvilinear furrows is mapped, aligned to the trough axis. The furrows occur in water depths of c. 690-720 m, have lengths up to $c .12 \mathrm{~km}$ and often demonstrate considerable relief ( $>20 \mathrm{~m}$ in height).

Regular, low-amplitude sedimentary ridges (corrugation ridges) are superimposed on the furrows perpendicular to the trough axis (Fig. 3c). Corrugations are 1-2 $\mathrm{m}$ from trough to crest and have wavelengths of $60-200 \mathrm{~m}$. Their spacing decreases downflow and their amplitudes have a dominant cyclicity at 14 ridges (Jakobsson et al. 2011). Mapped here in detail (Fig. 3d), the corrugation ridges overprint furrows extensively north of GZW4. Where the furrows extend into shallower-water depths downstream, they frequently terminate in large crescentic ridges which are regularly $>10 \mathrm{~m}$ in relief (Fig. 3e). Slightly steeper ice-proximal slopes and orientation of the crescent apex indicate a pushing mechanism from the south.

\section{Outer-shelf trough and upper continental slope}

Beyond the ridges, PITE is less pronounced. The trough outlet at its deepest part is narrow $(c .15 \mathrm{~km})$ but trough depth and relief decrease as the seafloor shoals seaward. This suggests that ice flow on the outer shelf was unrestricted by underlying topography. Within the trough axis, two further sediment wedges are partially mapped (GZW1 and GZW2; Fig. 3f). Both are scoured on their tops by crudely aligned furrows that terminate at the wedge crests. GZW1 extends for c. $19 \mathrm{~km}$ to underlie GZW2 whose extent is uncertain. GZW1 is $c .15 \mathrm{~m}$ thick, while GZW 2 may be $>40 \mathrm{~m}$ high. Equivalent and probably corresponding wedges are also mapped to the east in Abbot Trough (not shown; Klages et al. 2015).

The outermost shelf and trough flanks are among the shallowest parts of the continental margin and, therefore, dominated by regions of curvilinear randomly orientated and cross-cutting furrows. The upper slope beyond a broadly arcing shelf edge exhibits zones of extensive gullies (Dowdeswell et al. 2006).

\section{Interpretation of landforms}

\section{Inner embayment}

The lineations imaged under Pine Island Glacier ice shelf (Fig. 2b) show dimensions, sinusoidal cross-profiles and parallel, streamlined geometries typical of mega-scale glacial lineations (MSGLs) mapped on the beds of modern and palaeo-ice streams. Their association with a modern glacier setting and identical alignment to modern ice-shelf flow leave little doubt that these lineations formed subglacially during the most recent episodes of glacier grounding, which probably served to plane off the distinctive ridge crest on which they are observed.

The possible origin of corrugations observed between the linear bedforms on top of the sub-ice-shelf ridge (Fig. 2c) and elsewhere 


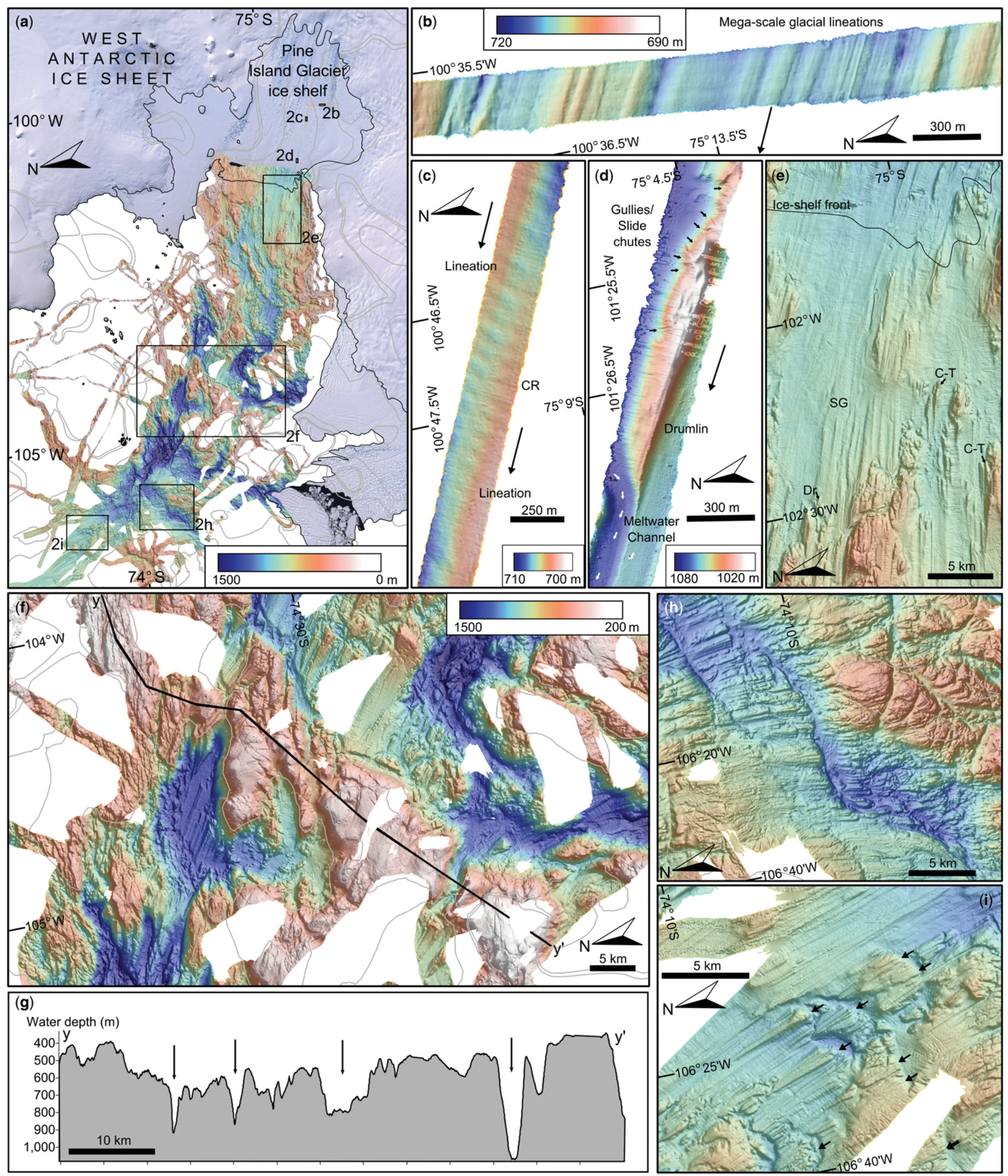

Fig. 2. Marine-geophysical data from the inner to middle shelf in front of Pine Island and Thwaites glaciers. (a) Multibeam-bathymetric data for inner Pine Island Bay. Main acquisition systems Kongsberg EM120 (RRS James Clark Ross). Frequency 12 kHz; Atlas Hydrosweep DS-2 (RV Polarstern). Frequency 15.5 kHz; SeaBeam 2100 (R/V Nathaniel B. Palmer). Frequency $12 \mathrm{kHz}$. Grid-cell sizes 30-50 m. (b-d) High-resolution (2 m grid-cell size) AUV swath-bathymetric data collected on Autosub mission M434 beneath Pine Island Glacier ice shelf showing (b) streamlined lineations, (c) corrugated ridges (CR), and (d) heavily streamlined drumlinoid landforms, respectively. Direction of modern ice-shelf flow/inferred palaeo-flow shown by black arrows. Small black arrows in (d) illustrate chutes, while small white arrows follow axis of sinuous, erosive channel. Locations in (a). (e) Streamlined grooves (SG), crag-and-tails (C-T) and drumlinoid (Dr) features in Pine Island Bay (grid-cell size $30 \mathrm{~m}$ ). Colour scale as for (a). (f) Major cross-trough sill on the inner shelf surrounded by a series of deep basins and inter-connecting channels. (g) Depth profile across the sill crest showing regular breaches (arrowed). (h) Grooved and drumlinized ice-moulded seafloor, cross-cut by geological structures and/or remnant meltwater channels. Colour scale as for (a). (i) Evolution of landforms in (h) into more regular, parallel and streamlined lineations, interspersed with large crag-and-tail landforms with prominent crescentic scours around their up-ice heads (black arrows). Colour scale as for (a). 
in Pine Island Trough has been debated (Graham et al. 2013). The rhythmic pattern in height and spacing in both sets of corrugations likely represents a tidal modulation (Jakobsson et al. 2011), while their subtle form and transverse expression fits an ice-keelgrounding interpretation (alongside several other plausible mechanisms; see discussion in Graham et al. 2013). For the particular set of features under Pine Island Glacier ice shelf, the periodic grounding of sub-ice-shelf keels during the final phases of glacier unpinning has been proposed as the most likely formation mechanism. The physical process underpinning this hypothesis is similar in nearly all aspects to the alternative model proposed by Jakobsson et al. (2011) to explain identical corrugations in Pine Island Trough (Fig. 3d), in which the landforms were produced at the trailing margin of icebergs entrained in a mélange of brash and sea ice.

Smoother areas of the seafloor on the inner shelf are sedimentary basins, recording either successive phases of Quaternary environmental history or more recent late glacial-Holocene fill (e.g. Fig. 2e). High subglacial erosion rates (Smith et al. 2012) and rapid ice discharge inferred from adjacent ice streams imply rapid delivery of glacigenic sediment during the late Quaternary. Outside these localized sediment infills, crystalline bedrock at the seafloor exerts a strong influence on the landforms. Crag-and-tails, drumlinoid ridges and streamlined grooves are all interpreted as subglacial bedforms, moulded and shaped over successive glaciations of the continental shelf. Similarly to its analogous bedform assemblage in the western Amundsen Sea, the shelf landsystem in inner Pine Island Bay is complex locally and does not show a simple downflow evolution of bedforms as had been suggested previously for some West Antarctic ice streams (e.g. Wellner et al. 2001).

Bedrock sills and intervening rock basins are interpreted as the product of both successive phases of direct subglacial erosion, and a superimposed history of erosion via palaeo-meltwater discharge (Lowe \& Anderson 2003). The latter was mapped by Nitsche et al. (2013) who interpreted the interconnected network of basins and deep channels as evidence for substantial phases of meltwater flow at the base of former ice streams. The sills themselves probably served as pinning points for the ice sheet during previous configurations in which the West Antarctic Ice Sheet had advanced and retreated across the shelf. This almost certainly includes the retreat across this sector following the LGM. Breaches in the sills attest to outflow of water under pressure (Fig. 2f, g). Rare tunnel valleys are interpreted as strong evidence for subglacial meltwater conduits, confirming substantial erosion by discharge of significant quantities of water under past ice sheets.

\section{Mid-shelf trough}

Meltwater features diminish seaward to be replaced by landforms interpreted as streamlined subglacial bedforms, such as drumlinoid features and bedrock grooves. The highly parallel sedimentary lineations into which these transition, as with bedforms under the modern ice shelf, are interpreted as MSGLs recording till deformation at the base of a former fast-flowing ice stream.

The sedimentary wedges that are common on the middle and outer shelf of Pine Island Trough are grounding-zone wedges, grounding-line depositional bodies interpreted to have formed during stillstands ('stable' phases) or following minor readvances interrupting ice retreat from a more expanded outer-shelf extent. The occurrence of the wedges within a trough formed by, and found seaward of, modern fast-flowing ice streams, and the simultaneous association with MSGLs as well as water-saturated dilatant till, indicates that the wedges are the products of deposition by past ice streams. We interpret the wedges as having been produced over time by a repeated combination of subglacial till advection and debris-flow deposition in front of the grounding line. The series of five wedges and transverse ridges in the Pine Island Trough together record the shallowing of the grounding line in a landward direction during post-LGM episodic retreat.
MSGLs occur on the back-slope of GZW4, but the shallow surface of GZW5 has been imprinted by drifting icebergs, leaving random furrows interpreted as iceberg ploughmarks (Fig. 3b). Longer and more linear furrows that occur seaward of GZW4 have been interpreted as part of an assemblage of landforms that includes the corrugations which overprint them and crescentic ridges at their termini. Together, these features reflect phases of ice-shelf break-up during the last deglaciation of the Pine Island-Thwaites ice stream (Fig. 3d, e). The ploughmarks were formed by iceberg keels, entrained in an armada of brash- and sea-ice which calved from a rapidly collapsing ice shelf and ran aground on shallower topography forming crescentic push ridges in the process (Jakobsson et al. 2011). Tidal modulation led many of the icebergs to ground periodically on the seafloor during their passage along the trough. The rising and falling of the ice keels formed a suite of corrugations overprinting the ploughmarks, analogous to those mapped under Pine Island Glacier ice shelf. Assuming one ridge was produced per day, the strong periodicity in the corrugations reflects a spring-neap (14 day) tidal cycle, while the seaward reduction in their spacing is consistent with a decrease in drift velocity as the icebergs floated away from the calving front.

\section{Outer shelf and upper slope}

Sedimentary grounding-zone wedges in the PITE also have sets of linear furrows on their back-slopes (GZW1 and 2). These are interpreted as subglacial landforms, with their low parallel conformity and occasional cross-cuts reflecting dynamic variations in the grounding zone as it nears flotation (Graham et al. 2010).

\section{Discussion: landform distribution and schematic model}

A simplified schematic map of the landforms and their distribution in the Pine Island Trough system is shown in Figure 4a. With steadily increasing multibeam coverage in the eastern Amundsen Sea over the past 15 years (Wellner et al. 2001; Lowe \& Anderson 2003; Graham et al. 2010; Jakobsson et al. 2012; Nitsche et al. 2013), this palaeo-ice-stream system is now among the most wellstudied anywhere in Antarctica.

The Pine Island-Thwaites ice-stream system is also the first landsystem mapped fully from modern grounding line to continental shelf edge and upper slope, taking into account geomorphic features still covered by the intact floating portions of the West Antarctic Ice Sheet.

Subglacial bedforms are imaged beneath Pine Island Glacier ice shelf in an area where the headroom between the ice-shelf base and ocean floor is narrow (c. 200-300 m). Unpinning of the ice shelf started in the 1970s and current changes are thought to be a continuation of that retreat (Jenkins et al. 2010). At least locally, these bedforms are probably emergent features of twentieth-century grounding-line recession. An interesting question is how such bedforms are preserved during the physical transition from grounded to floating glacier that is known to have occurred in this region. Features interpreted to represent ice-shelf-keel contact forms are manifest as corrugations within streamlined ridge-grooves under the ice shelf, and may represent one distinctive signature of ice-shelf-seafloor contact that can help answer this question. However, the age, context and distribution of such landforms are currently unclear and remain a focus of further enquiry.

As with many palaeo-ice-stream systems around Antarctica, the contrast between a bedrock-floored inner shelf and, seaward, a seafloor underlain by sedimentary strata is shown to be a strong control on the geomorphological signatures along the length of Pine Island Trough (Fig. 4a). On the rugged, bedrock-floored inner shelf, a complex assemblage of erosional features, formed by multiple glacial cycles of advance and retreat, is juxtaposed against more recent erosional landforms and localized sediment-infilled 


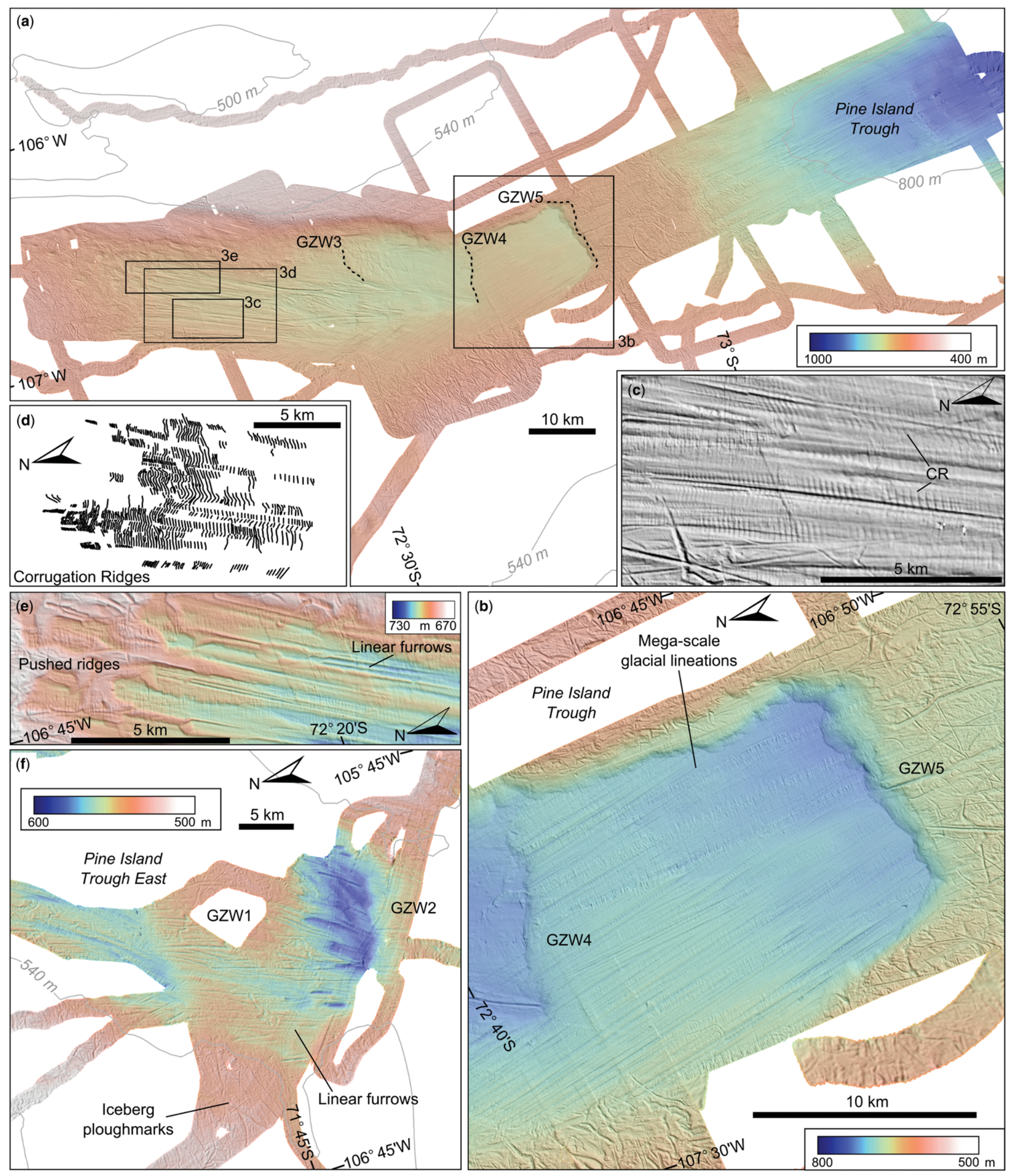

Fig. 3. Marine-geophysical data from the middle to outer shelf of Pine Island Trough. (a) OS09/10 (RV Oden) multibeam dataset from the centre of Pine Island Trough (Acquisition system Kongsberg EM122. Frequency $12 \mathrm{kHz}$. Grid-cell size $20 \mathrm{~m}$; see Jakobsson et al. 2012), highlighting three major grounding-zone wedges (GZWs). (b) Hill-shaded multibeam-bathymetric data for the two largest GZWs, illustrating streamlined (and corrugated) lineations on top of GZW4 and irregular cross-cut ploughmarks on top of GZW5. Lobate debris-flows characterize the foot of GZW5. Note the restriction of GZWs to the narrow trough in this location. (c) Hill-shaded image of corrugation ridges (CR) overprinting ice-ploughed furrows seaward of GZW3-5. (d) Map of corrugation ridges digitized from multibeambathymetric data showing extensive seafloor coverage. (e) Ice-keel ploughmarks terminating in crescentic push ridges at the shoaling edge of Pine Island Trough. (f) Two further GZWs in the outer parts of Pine Island Trough East, with crudely parallel lineations or ice-keel ploughmarks on their backslopes (Acquisition system Kongsberg EM120. Frequency $12 \mathrm{kHz}$. Grid-cell size $50 \mathrm{~m}$; see Graham et al. 2010). These wedges mark the outermost signature of ice grounding on the continental shelf. 


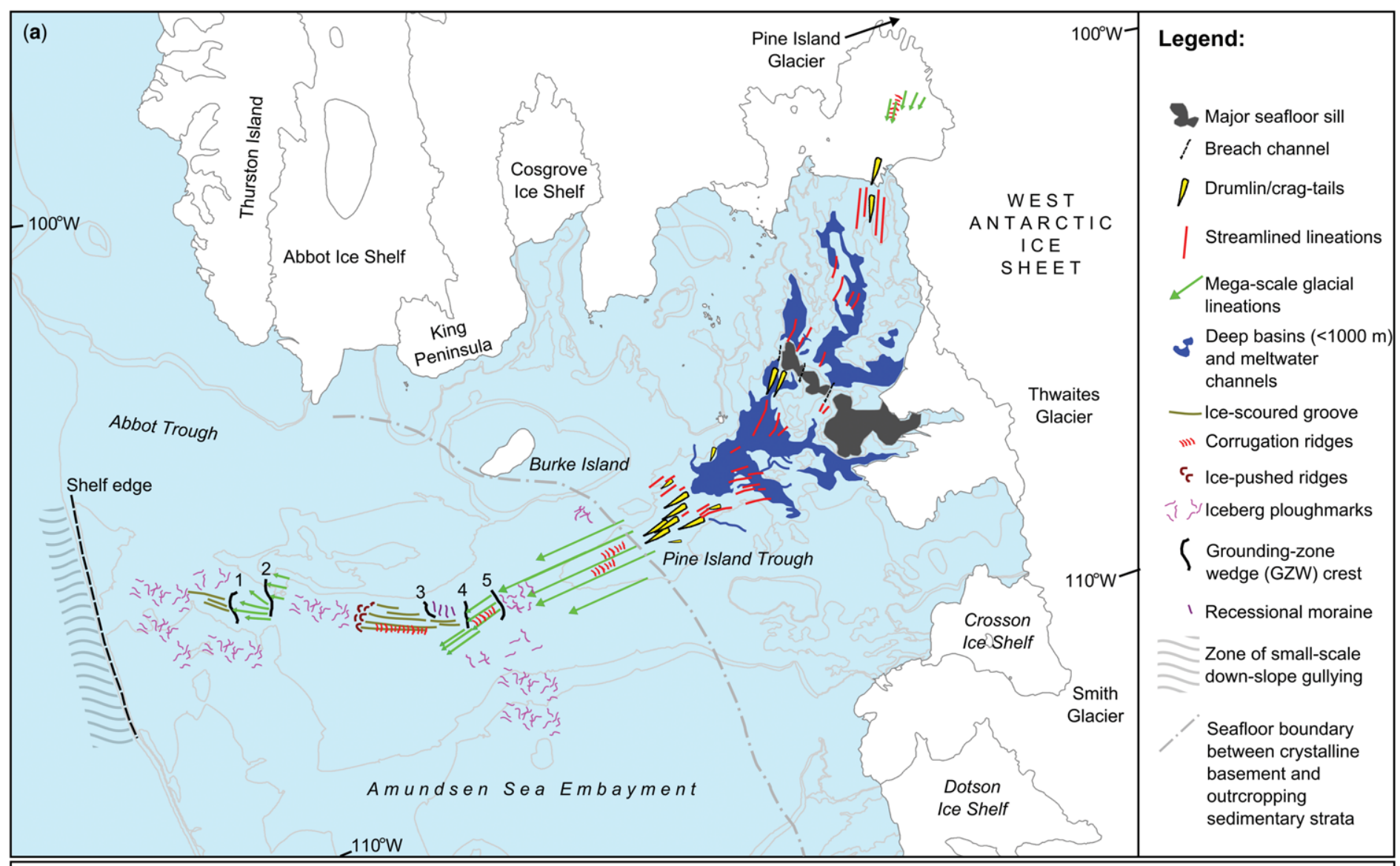

(b)

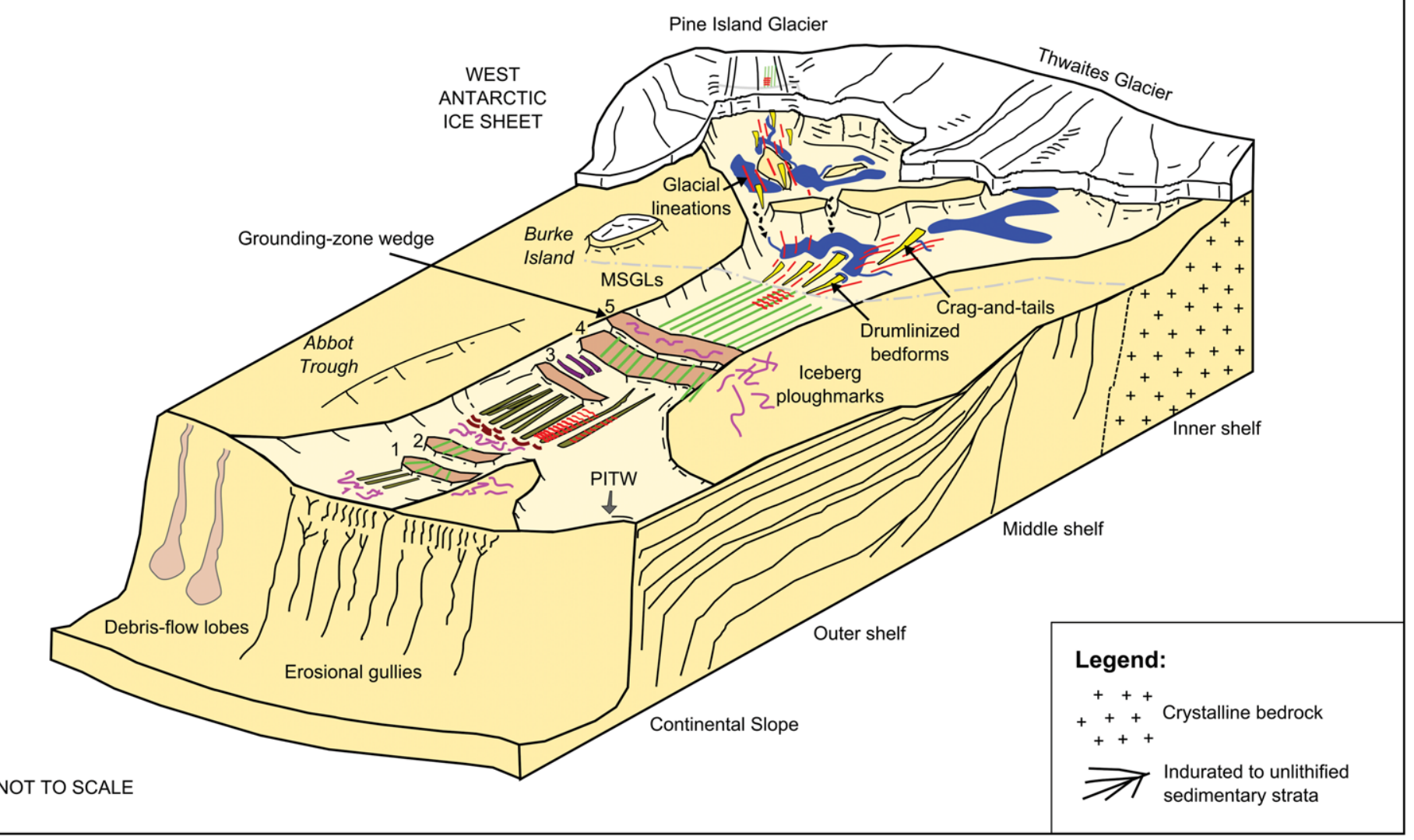

Fig. 4. (a) Summary diagram of the distribution pattern of submarine landforms in the Pine Island-Thwaites system, West Antarctica (synthesized from Lowe \& Anderson 2002; Graham et al. 2010; Jakobsson et al. 2011, 2012; Nitsche et al. 2013). Note that the depiction of the landforms is much simplified from reality. (b) Schematic landform-assemblage model for the grounding-line-to-slope landform system in the eastern Amundsen Sea Embayment. GZWs numbered 1-5. The model includes a representative stratigraphy for the West Antarctic continental shelf based on the interpretation of seismic profiles (Gohl et al. 2013). Legend for landforms in (a) is also applicable to the schematic model in (b). 
basins. In contrast, the sediment-floored middle-to-outer shelf parts of the trough record the maximum extent of the last glaciation and subsequent retreat stillstands of the ice sheet, dominated by events related to the dynamics of the grounding line and ice shelf during deglaciation. To add to the temporal complexity of the landscape, such a transition in substrate and topography probably also influenced the dynamics of the overlying ice stream (e.g. promoting fast flow over sediment basins during full-glacial conditions) and its deglaciation (e.g. by providing pinning points and through changes in bed geometry along flow), which we suggest has further influenced the resulting ice-stream geomorphological signature.

A further important control on ice-stream dynamics relates to the width of the trough which the glacier occupies, which serves to restrict ice discharge at the grounding line (Jamieson et al. 2012). The Pine Island-Thwaites ice stream is a good example of a system affected by a convergent bottleneck in trough geometry at $c .73^{\circ} \mathrm{S}$ which, through regulating discharge and increasing lateral drag, has led to grounding-line 'stability' and hence the construction of large sediment wedges at the grounding line on the middle shelf. We postulate that some of the pauses are not controlled simply by trough geometry and may instead relate to iceshelf pinning and buttressing, as well as to pronounced changes in seafloor gradient along the trough axis. In either case, the resulting landsystem reflects episodic retreat of an ice stream, with steps of fast retreat punctuated by pauses in deglaciation.

An aspect of our landform interpretation not captured in previous landsystem models for marine palaeo-ice streams is the importance of floating ice as a major geomorphic agent on the continental shelf. This is manifest in the model in three ways: (1) in suites of furrowed bedforms and plough ridges interpreted as the result of iceberg breakouts from ice shelves; (2) in corrugation ridges that reflect ice-keel grounding behind iceberg armadas or under intact ice shelves; and (3) in cross-cutting iceberg ploughmarks that formed during ancient and recent iceberg grounding events. Evidence for interaction of floating ice with the seafloor occurs extensively across the trough model, from the shelf edge to locations beneath the floating ice tongue, and is here recognized as a key component that may yet prove important in landform systems of other Antarctic palaeo-ice streams.

Surprisingly for a cold polar margin, meltwater features are also well developed in the landsystem. To generate substantial amounts of erosion from surface melt would require periods of landscape evolution during substantially warmer Antarctic climate conditions than today, which may be implausible even for warm interglacials. Alternatively, several of the mapped basins in inner Pine Island Bay are interpreted to have captured, stored and discharged water periodically (Nitsche et al. 2013) as reported for modern subglacial lakes in Antarctica. It is therefore more likely that episodic discharges of subglacial water played a dominant role in generating the meltwater-carved landforms we have mapped.

Finally, by comparison with some Antarctic Peninsula palaeoice streams (Livingstone et al. 2012), the ice-flow landform indicators and bedform patterns on the outer shelf are poorly developed for such a major palaeo-ice stream. Some MSGLs do occur in the axis of PITE, but outside the deepest parts they are obliterated by repeated erosion via iceberg activity; the distribution of streaming ice on the outer shelf therefore remains difficult to quantify. However, a flattening in trough profile beyond the mid-shelf and the existence of multiple outer-shelf troughs, including new landform evidence of streaming ice within Abbot Trough (Fig. 1b; Klages et al. 2015), raises the possibility that outer parts of the ice sheet were configured in widespread distributed fast ice flow or even as divergent fast-flowing trunks during glacial maxima (Graham et al. 2010). Although we cannot constrain the precise glaciological regime, it is evident from recent mapping that the geomorphological character of the outer shelf is as complex as the inner-shelf counterpart, and not a relatively simple imprint of full-glacial conditions (cf. Marguerite Trough).

\section{References}

Dowdeswell, J.A., Evans, J., Ó Cofaigh, C. \& Anderson, J.B. 2006. Morphology and sedimentary processes on the continental slope off Pine Island Bay, Amundsen Sea, West Antarctica. Geological Society of America Bulletin, 118, 606-619.

Evans, J., Dowdeswell, J.A., Ó Cofaigh, C., Anderson, J.B. \& BenHAM, T.J. 2006. Extent, dynamics and processes of the West Antarctic Ice Sheet on the outer continental shelf of Pine Island Bay, Amundsen Sea, Antarctica during the last glaciation. Marine Geology, 230, $53-72$.

Gohl, K., Uenzelmann-Neben, G. ET AL. 2013. Seismic stratigraphic record of the Amundsen Sea Embayment shelf from pre-glacial to recent times: evidence for a dynamic West Antarctic ice sheet. Marine Geology, 344, 115-131.

Graham, A.G.C., LARTER, R.D. ET AL. 2010. Flow and retreat of the Late Quaternary Pine Island-Thwaites palaeo-ice stream, West Antarctica. Journal of Geophysical Research, 115, F03025.

Graham, A.G.C., DutrieuX, P. ET AL. 2013. Seabed corrugations beneath an Antarctic ice shelf revealed by autonomous underwater vehicle survey: origin and implications for the history of Pine Island Glacier. Journal of Geophysical Research, 118, 1356-1366.

Hillenbrand, C-D., Kunn, G. ET AL. 2013. Grounding-line retreat of the West Antarctic Ice Sheet from inner Pine Island Bay. Geology, 41, $35-38$.

Jakobsson, M., ANDERSOn, J.B. ET AL. 2011. Geological record of ice shelf break-up and grounding line retreat, Pine Island Bay, West Antarctica. Geology, 39, 691-694.

JAKOBSSON, M., ANDERSON, J.B. ET AL. 2012. Ice sheet retreat dynamics inferred from glacial morphology of the central Pine Island Bay Trough, West Antarctica. Quaternary Science Reviews, 38, 1-10.

JAMIESON, S.S.R., VIELI, A. ET AL. 2012. Ice-stream stability on a reverse bed slope. Nature Geoscience, 5, 799-802.

Jenkins, A., Dutrieux, P. eT AL. 2010. Observations beneath Pine Island Glacier in West Antarctica and implications for its retreat. Nature Geoscience, 3, 468-472.

Kirshner, A., ANDERson, J.B. ET AL. 2012. Post-LGM deglaciation in Pine Island Bay, West Antarctica. Quaternary Science Reviews, 38, 11-26.

Klages, J.P., Kuhn, G. ET AL. 2015. Palaeo-ice stream pathways and retreat style in the easternmost Amundsen Sea Embayment, West Antarctica revealed by combined multibeam bathymetric and seismic data. Geomorphology, 245, 207-222.

LARTER, R.D., ANDERSON, J.B. ET AL. 2014. Reconstruction of changes in the Amundsen Sea and Bellingshausen Sea sector of the West Antarctic Ice Sheet since the Last Glacial Maximum. Quaternary Science Reviews, 100, 55-86.

Livingstone, S.J., Ó Cofaigh, C., Stokes, C.R., Hillendrand, C.-D., VIeLI, A. \& JAMIESON, S.S.R. 2012. Antarctic palaeo-ice streams. Earth-Science Reviews, 111, 90-128.

Lowe, A.L. \& ANDERSON, J.B. 2002. Reconstruction of the West Antarctic Ice Sheet in Pine Island Bay during the Last Glacial Maximum and its subsequent retreat history. Quaternary Science Reviews, 21, $1879-1897$

Lowe, A.L. \& ANDERson, J.B. 2003. Evidence for abundant subglacial meltwater beneath the paleo-ice sheet in Pine Island Bay, Antarctica. Journal of Glaciology, 49, 125-138.

Nitsche, F.O., GoHL, K. ET AL. 2013. Paleo ice flow and subglacial meltwater dynamics in Pine Island Bay, West Antarctica. Cryosphere, 7, 249-262.

Rignot, E., Bamber, J.L. ET AL. 2008. Recent Antarctic ice mass loss from radar interferometry and regional climate modelling. Nature Geoscience, 1, 106-110.

Smith, A.M., Bentley, C.R., Bingham, R.G. \& Jordan, T.A. 2012. Rapid subglacial erosion beneath Pine Island Glacier, West Antarctica. Geophysical Research Letters, 39, L12501.

Smith, J.A., Hillendrand, C.-D. ET AL. 2014. New constraints on the timing of West Antarctic ice sheet retreat in the eastern Amundsen Sea since the Last Glacial Maximum. Global and Planetary Change, 122, 224-237.

Wellner, J.S., Lowe, A.L., Shipp, S.S. \& ANDERson, J.B. 2001. Distribution of glacial geomorphic features on the Antarctic continental shelf and correlation with substrate: implications for ice behaviour. Journal of Glaciology, 47, 397-411. 